\title{
First report of Faunus ater (Pachychilidae: Gastropod) on the American Continent: A mature empty specimen from Masachapa, Nicaragua, Central America
}

\author{
Adolfo López S.J. and Janina Urcuyo \\ UCA Univ., Managua; alosi24@yahoo.com; janina@ns.uca.edu.ni
}

Received 23-III-2012 Corrected 11-VI-2012 Accepted 5-VIII-2012

\begin{abstract}
Faunus ater (Linné, 1758), a Pachychilid monotypic gastropod, is a well known brackish water snail from the Philippines and East Asia. In the year 1982 a single specimen was found in the estuary section of River Masachapa, Masachapa Town, on the Pacific coast of Nicaragua, 60 $\mathrm{km}$ from Managua. This trans-continental range extension is the first reported in the Americas.
\end{abstract}

\section{KEY WORDS}

Range extension, Asia-America, Pachychilidae, Faunus ater, Nicaragua.

\section{RESUMEN}

Faunus ater (Linné, 1758), es un gastrópodo pachiquílido monotípico de agua salobre, bien conocido en Filipinas y el sudeste asiático. Un único ejemplar fue hallado en el estuario del río Masachapa, en la costa del Pacífico nicaragüense a $60 \mathrm{~km}$ de Managua. Este hallazgo constituye una extensión de ámbito trans-continental, la primera para este género en las Américas.

\section{PALABRAS CLAVE}

Extensión de ámbito, Asia-América, Pachychilidae, Faunus ater, Nicaragua.
Faunus ater (translated as "Black Devil" from the Latin) is a well known brackish water snail from the Philippines and East Asia, where it is popular as food. The genus Faunus had not been reported until now in the Americas. However the family Pachychilidae (Fischer \& Crosse, 1892 is well represented there. In Nicaragua concretely (López \& Urcuyo, 2009), Pachychilus (Lea \& Lea, 1850) is a common freshwater snail in rivers and streams, such as $P$. largillierty (Phillipi, 1843), in the west, P. oerstedii (Möerch, 1861) in the central part, and as P. chrysalis (Brot, 1872) in the north and east of the country. These three species are very sensitive to water pollution and may be used as indicators of water quality for human consumption. The meat of the animals qualifies among country-folk as invigorating food.

\section{METHODOLOGY}

Faunus ater has eventually been placed in the Pachychilidae (Köler et al., 2004) after being assigned to various other families before. For a revision of its earlier taxonomy see Houbrick (1991)

Identification of species was made by comparing the specimen with samples of Faunus ater from the Philippines in the Los Angeles County Museum of Natural History (Fig. 1; LACM 96357), and with photographs depicted by Wenz, 1959.

The shell is outstanding on account of its large size, narrow conical profile (Fig. 1), and especially by its unique aperture (Fig. 2).

Adult specimens of Faunus ater grow to a maximum length of $90 \mathrm{~mm}, 20 \mathrm{~mm}$ diameter and about 15 whorls (Houbrick, 1991). Shell color is black in juveniles, turning to mahogany as the shell grows (Fig. 1). Each whorl bears two nearly equal color bands, the upper one of a lighter shade. Sculpture is of low, close, rounded spirals intersected by close vermicular striae (Fig. 2). The unique aperture is formed by a thick flaring lip with a wide, rounded siphonal canal and a $U$ shaped anterior canal, porcelain-white 
inside, turning to black internally (Fig. 2). Figures are in metric scale.

\section{RESULTS}

Only a single, mature specimen of Faunus ater was found in 1982, 70,1 $\mathrm{mm}$ length, 20,6mm diameter, 11 whorls, tip broken as is usual with adults of this species. It is an empty specimen, but in excellent color and condition, taken in the brackish water section of the Masachapa River, Masachapa Town, between the weir and the sea, together with a few samples of Melanoides tuberculata, a very common, invasive thiarid species in the rivers and lakes of Nicaragua (López \& Urcuyo, 2009).

Two further unsuccessful searches for Faunus were made in the estuary part of the river covering the beach, where the original specimen was located.

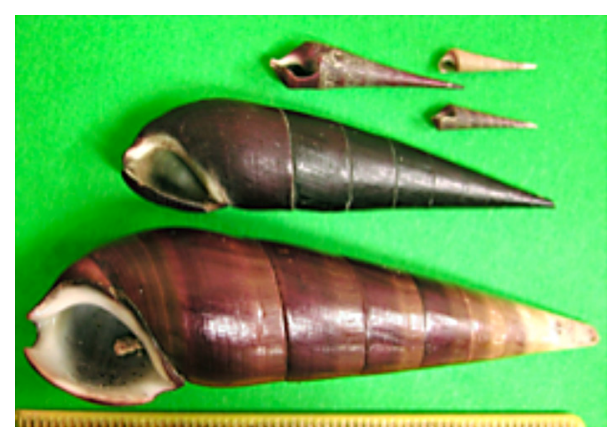

FIG. 1. F. ater, Masachapa spm.(below); four juvenile specimens; Philippines, LACM (above).

See all the photos of this paper in full color, in the digital version (www.uned.ac.cr/investigacio/publicaciones/ cuaderno1/).

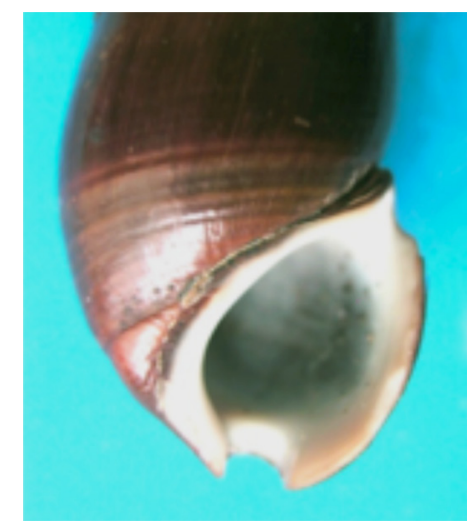

FIG. 2. F. ater, same Masachapa sample; aperture.

\section{DISCUSSION}

How the transfer of that single specimen across the 10000 mile expand of the Pacific Ocean could be made is difficult to imagine. Many marine mollusks posses a free swimming larva that may last for months. Such a veliger larva is also found in most marine Cerithioidea. Veligers can be carried by ocean currents for thousands of miles. The ontogenetic development of Faunus is unknown. However its wide distribution, which includes the mainland coast but also many small islands throughout the Indo-West Pacific region, indicates that it is capable of dispersal across shorter stretches of open sea. If the specimen in Nicaragua was not introduced by humans, it must have come as a larva, juvenile or mature specimen perhaps rafting on floating debris or from discharged ballast water of a ship.

If so, currents are a readily available transport media for this species. The Pacific North Equatorial Counter current, a powerful flow with a speed of one knot average, and a three knots maximum in summer, will carry a veliger or flotsam straight from the Philippines to Nicaragua (McPhaden, 1996).

Reasoning that any samples of Faunus which might have arrived by sea would not have climbed the dam wall into the river above, only the estuary part of the river on the beach below the dam (Fig. 3) was searched. Even if able to creep up the wall into the river, it is not to its advantage to move into fresh water, improper habitat for Faunus. Remaining below in the estuary it would be living in brackish water, swamped by sea water at high tide.

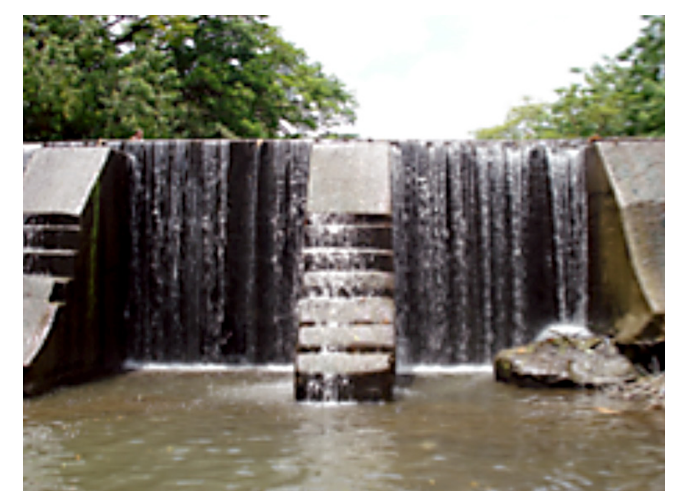

FIG. 3. Weir separating Masachapa river from estuary. 


\section{ACKNOWLEDGEMENTS}

Many thanks are due to the authorities of the Universidad Centroamericana (UCA), Managua, present and former, in special to Jaime Incer Barquero, former Dean of Arts and Sciences and to Roberto Zarruk, then Dean of Men, for their encouragement and support of the Malacology Center and its activities. Marvin Torrez offered corrections to the Manuscript. Further corrections and additions suggested by the editor and anonymous reviewers were also gratefully accepted.

\section{REFERENCES}

Fischer P.H., \& Crosse, J.C.H. (1892). Pour servir a I'histoire de la faune de IÁmerique Centrale et du Mexique. Paris: Imprimerie Nationale.

Houbrick, R.S. (1991). Anatomy and systematic placement of Faunus Montfort 1810 (Prosobranchia: Melanopsinae). Malacological Review, 24:35-54.
Köler, F., von Rintelen, T., Meyer, A. \& Glaubrecht, M. (2004). Multiple origin of viviparity in Southeast Asian gastropods (Cerithioidea: Pachychilidae) and its evolutionary implications. Evolution, 58:2215-2226.

Lea, I. \& Lea, H.C. (1850). Description of a new genus of the family of Melaniana, and of many new species of the genus Melania, chiefly collected by Hugh Cuming, Esq., during his zoological voyage in the East, and now first described. Proceedings of the Zoological Society of London 18:179-246.

López, Al \& Urcuyo, J. (2009). Moluscos de Nicaragua II, Gastrópodos. UCA, Managua, Nicaragua: Marena-Araucaria.

McPhaden, M.J. (1996). Monthly periodic oscillation in thePacific North Equatorial Countercurrent. Jr. Geophysical Res, 101: 6337-6359

Wenz, W. \& Zilch, A. (1959). Gastropoda. Handbuch der Palaeozoologie. Berlin: Gebrüder Borntraeger. 